\title{
Modified Atmosphere Packaging of Cut Welsh Onion: Effect of Micro-Perforated Polypropylene Film Packaging on Chemical Components and Quality Stability of the Vegetable
}

\author{
Toshiyuki IBARAKI, ${ }^{1}$ Toshinao ISHII, ${ }^{2}$ Emi IKEMATSU, ${ }^{2}$ Hironobu IKEDA ${ }^{1}$ and Hideaki OHTA ${ }^{2}$ \\ 'Fukuoka Agricultural Research Center, 578 Yoshiki Chikushino, Fukuoka 818-8549, Japan \\ ${ }^{2}$ Department of Food Science and Nutrition, Nakamura Gakuen University, 5-7-1 Befu, Jonan-ku Fukuoka 814-0198, Japan
}

Received December 7, 1999; Accepted February 10, 2000

\begin{abstract}
The chemical components and quality stability of pre-cut Welsh onion wrapped in an unperforated or micro-perforated orientated polypropylene (OPP) film package were evaluated during storage at $10^{\circ} \mathrm{C}$. The concentration of oxygen $\left(\mathrm{O}_{2}\right)$ in the unperforated OPP package decreased rapidly to $2 \%$ while that of carbon dioxide $\left(\mathrm{CO}_{2}\right)$ increased. Therefore, the onion underwent anaerobic respiration, ethyl alcohol was produced and some of the chemical components were lost. Moreover the cellular tissue of the vegetable became water-soaked. The $\mathrm{O}_{2}$ concentration in the OPP film package with too many micro-perforations decreased slightly, so that ethyl alcohol was not detected but there was a loss of chemical components. The quality of the product was diminished and the onion was unmarketable after 6 days of storage. For cut Welsh onion packed in perforated OPP film (with 24 micro-perforations), the $\mathrm{O}_{2}$ concentration in the package was not as low as in the modified atmosphere packaging for onion, but did decrease to $10 \%$. Ethyl alcohol could not be detected and there was no or only slight loss of chemical components, so that the onion was still marketable after 6 days of storage.
\end{abstract}

Keywords: pre-cut Welsh onion, micro-perforated film packaging, modified atmosphere packaging

Lightly processed vegetables are used by restaurants and food service industries in Japan to save on manpower for such preparation as peeling, washing and cutting (shredding). Such vegetables are increasingly being selected by consumers who wish to reduce processing time and residue. Welsh onion, which is usually used for seasoning, is sliced crosswise for cooking; therefore, lightly processed Welsh onion is also desired consumers.

Whole Welsh onions are sold using the technique of modified atmosphere packaging (MAP) which reduces respiration and loss of chemical components and delays the withering of leaf tips (Ibaraki et al., 1995). Oriented polypropylene (OPP) film is used to pack this onion because of its transparency and adaptability (Ibaraki et al., 1999), but the gas permeability of this film is too low to maintain the quality of the onion. Recently, OPP film with micro-perforations has been developed in an effort to prevent anaerobic respiration. The gas permeability of this film is determined by the film itself and the number and size of perforations (Hirata et al., 1996), so by adjusting the diameter and number of micro-perforations, the gas permeability of this film can be made suitable for many different vegetables. In addition to MAP, the temperature of transportation and storage is also a critical factor in maintaining the quality of lightly processed vegetables. Sugawara et al. (1987) reported that the temperature of shredded lettuce during practical distribution was around $10^{\circ} \mathrm{C}$.

In the present study, the gas concentration in the film package and chemical components of pre-cut Welsh onion packed in unperforated or micro-perforated OPP film were evaluated at a sim-

E-mail: ibaraki@farc.pref.fukuoka.jp ulated temperature of $10^{\circ} \mathrm{C}$.

\section{Materials and Methods}

Plant materials Welsh onions cv. Kujyo were obtained from unheated greenhouses in Fukuoka, Japan. Only undamaged onions were used. They were cut crosswise (width, $5 \mathrm{~mm}$ ) using a food processor (Welsh onion slicer SW-820: CHUBU Co., Ltd.) and used for analysis. Fifty grams of cut onion was then sealed in unperforated or micro-perforated OPP film packages and stored at $10^{\circ} \mathrm{C}$.

Plastic film packages The thickness, effective area and free volume of the OPP film bag was $0.02 \mathrm{~mm}, 0.043 \mathrm{~m}^{2}$ and $350 \mathrm{ml}$, respectively. $\mathrm{O}_{2}, \mathrm{CO}_{2}$ and $\mathrm{N}_{2}$ permeability coefficients $\left(\mathrm{ml} / \mathrm{m}^{2} /\right.$ day $\left./ \mathrm{atm}\right)$ of this film were 970,2420 and 150 , respectively. The film was perforated with laser beams; diameter of the perforations was $50 \mu \mathrm{m}$ (Fig.1), and the number of perforations per bag was either 24 or 48 . The combined permeabilities of both the film surface and the perforations are shown in Table 1.

Measurement of gas concentrations in the package The atmosphere in the package was determined by inserting a syringe through rubber tape $(15 \mathrm{~mm} \times 15 \mathrm{~mm})$ stuck to the film surface. $\mathrm{O}_{2}, \mathrm{CO}_{2}$ and $\mathrm{N}_{2}$ concentrations in the package were periodically determined using a Shimadzu GC-8A gas chromatograph (thermoconductivity detector, column: $1 \mathrm{~m}$ Porapak $\mathrm{N}$ and $3 \mathrm{~m}$ molecular sieve, column oven temperature: $80^{\circ} \mathrm{C}$ ). The ethylene concentration in the package was periodically determined using a gas chromatograph (flame ionization detector, column: $0.2 \mathrm{~m}$ Porapak Q, column oven temperature: $70^{\circ} \mathrm{C}$ ).

Ethyl alcohol content To confirm the anaerobic respira- 
tion, the ethyl alcohol production of cut Welsh onion was measured. Cut onion was soaked in distilled water and centrifuged at $3000 \times g$ for $10 \mathrm{~min}$. Ethyl alcohol in the supernatant fluid was measured using an F-kit [Beutlar \& Michal (1977), (Boehringer Mannheim Inc.)].

Sucrose, glucose and fructose content Cut onion (1 g) was homogenized with 10 times $5 \%$ meta phosphoric acid volume and centrifuged at $12,000 \times g$ for 5 min. Supernatant liquid was used for F-kit assay [Bergmeyer \& Bernt (1974), (Boehringer Mannheim Inc.)]

Chlorophyll content Cut onion (5 g) was homogenized with $80 \%$ ethyl alcohol and filtered through filter paper (Toyo $5 \mathrm{~B})$. The residue was washed with $80 \%$ ethyl alcohol until it became colorless, and the filtrate was added to this alcohol up to $50 \mathrm{ml}$. Chlorophyll determination was carried out as described by Wintermas and Demonts (1956).

Electric conductivity To confirm the collapse of the cellular tissue, the electric conductivity(EC) was measured. Cut onion $(50 \mathrm{~g})$ was incubated with 10 times the volume of distilled water for $2 \mathrm{~h}$. The leaked electrolyte solution of the tissue was filtered through filter paper (Toyo No.2). The filtrate was used for this analysis. EC was determined using an electric conductivity meter (HORIBA, DS-12).

Quality attributes The unpleasant odors and overall quality of cut onion in each package were evaluated just after the packages were opened. The unpleasant off-odors and overall quality of the vegetable were evaluated using a rating scale of 4 to 0 . Onions with a rating of 4 had quality comparable to that just after cutting, while a rating of 2 indicated marketable, and a rating of 0 indicated inedible.

\section{Results}

The $\mathrm{O}_{2}$ concentration in the unperforated OPP film package decreased rapidly and was $2 \%$ after one day of storage (Fig. 2A), while the $\mathrm{CO}_{2}$ content in this package increased and was

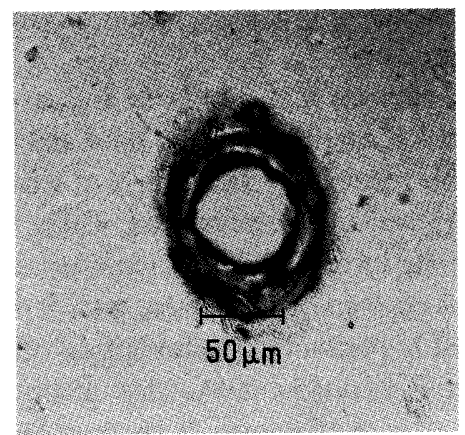

Fig. 1. Micro-perforation with laser beams.

Table 1. Gas permeability of unperforated or perforated OPP film at $10^{\circ} \mathrm{C}$.

\begin{tabular}{lcrrr}
\hline \multirow{2}{*}{ Property } & \multirow{2}{*}{ Thickness $(\mathrm{mm})$} & \multicolumn{3}{c}{ Permeability $\left(\mathrm{ml} / \mathrm{m}^{2} /\right.$ day/atm $)$} \\
\cline { 3 - 5 } & & \multicolumn{1}{c}{$\mathrm{O}_{2}$} & \multicolumn{1}{c}{$\mathrm{CO}_{2}$} & \multicolumn{1}{c}{$\mathrm{N}_{2}$} \\
\hline A & 0.02 & 970 & 2,420 & 150 \\
B & 0.02 & 24,467 & 22,163 & 23,970 \\
C & 0.02 & 130,938 & 128,707 & 139,963 \\
\hline
\end{tabular}

A: unperforated OPP film, B: OPP film with 24 micro-perforations per package, C: OPP film with 48 micro-perforations per package.
$16 \%$ after one day and $28 \%$ after 5 days of storage. In the perforated B film package (OPP film package with 24 micro-perforations), the $\mathrm{O}_{2}$ concentration decreased gradually and was 10 $12 \%$ after 3 days, and the $\mathrm{CO}_{2}$ concentration was $9-12 \%$ after one day. In the perforated $\mathrm{C}$ film package (OPP film with 48 micro-perforations), the $\mathrm{O}_{2}$ and $\mathrm{CO}_{2}$ concentration was $16-17 \%$ and $4-5 \%$ after one day, respectively, and was steady.

Ethylene was detected after 6 days in cut onion packed in unperforated film, and after 8 days in those in other packages (data not shown).

The changes in ethyl alcohol content are shown in Fig. 3. Ethyl alcohol was detected only when the onion was packed in unperforated film: it was produced after 4 days and at 4 to 8 days was steady at $13-15 \mathrm{mg} / 100 \mathrm{~g}$; it reached $20 \mathrm{mg} / 100 \mathrm{~g}$ after 10 days.

The sucrose content of onions packed in unperforated film and perforated $\mathrm{C}$ film decreased gradually during storage; that of onion packed in perforated B film decreased only slightly (Fig. 4-I). The glucose content of onions packed in unperforated film and perforated $\mathrm{C}$ film decreased considerably and was $40-50 \%$ of the initial value by the 10th day (Fig. 4-II). The fructose con-
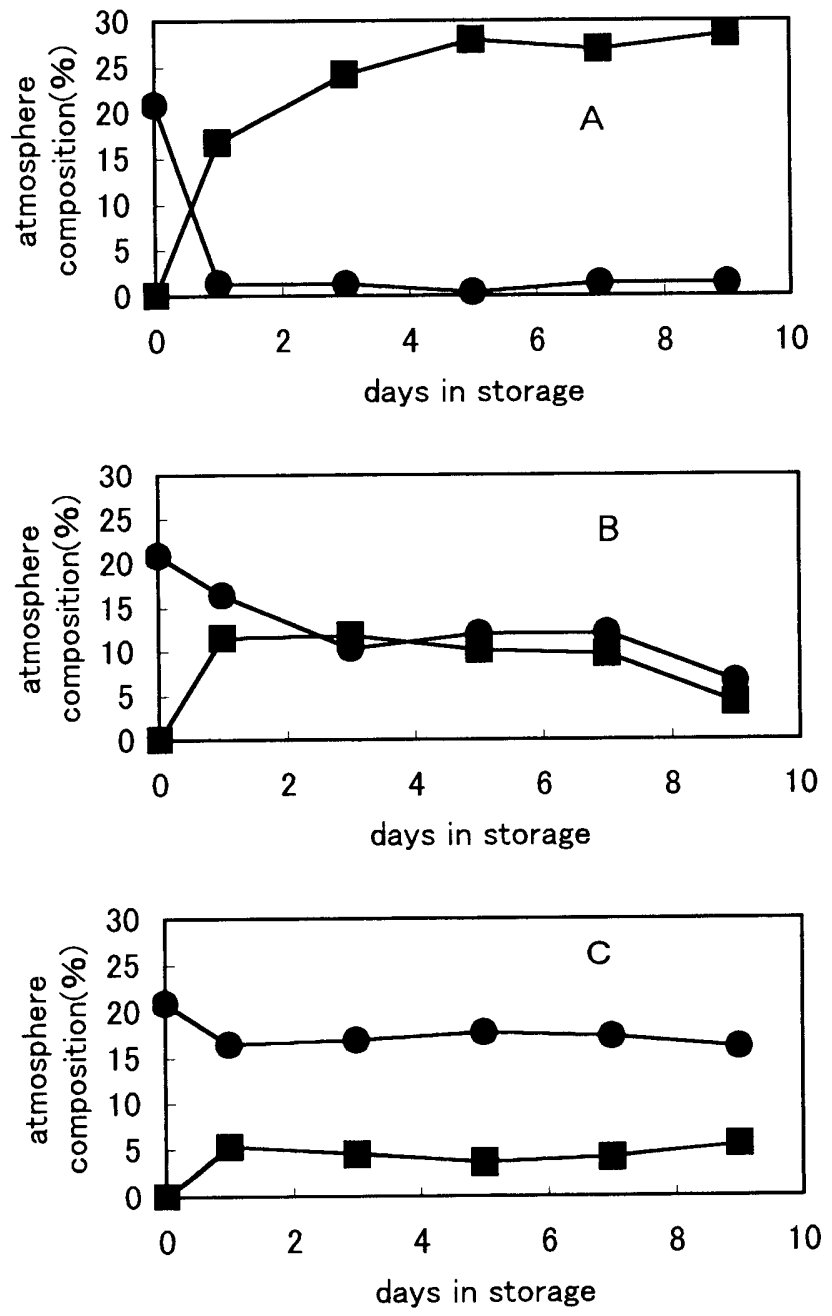

Fig. 2. Changes in $\mathrm{O}_{2}$ and $\mathrm{CO}_{2}$ concentrations in OPP film packages during storage at $10^{\circ} \mathrm{C}$. Data represent mean values of 4 determinations. A: unperforated OPP film, B: OPP film with 24 micro-perforations, C: OPP film with 48 micro-perforations, $\bullet$ : oxygen in package, $\mathbf{m}$ : carbon dioxide in package. 


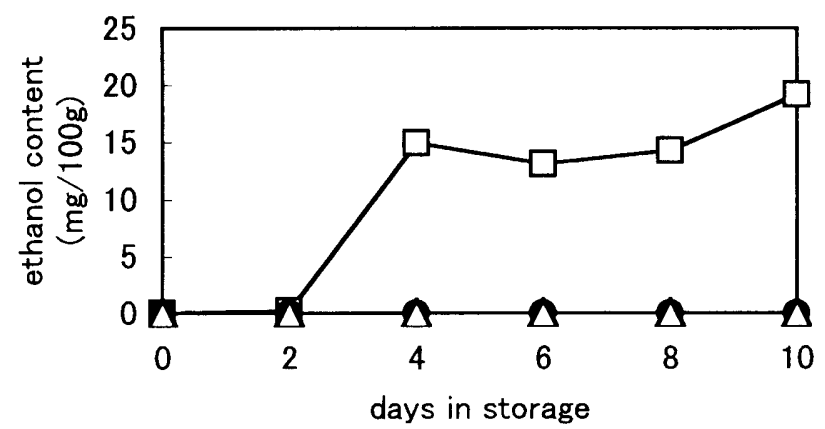

Fig. 3. Changes in ethyl alcohol content in cut onion during storage at $10^{\circ} \mathrm{C}$. Data represent mean values of 4 determinations. $\square$ : unperforated OPP film (A), $\bullet$ : OPP film with 24 micro-perforations (B), $\triangle$ : OPP film with 48 micro-perforations $(\mathrm{C})$.
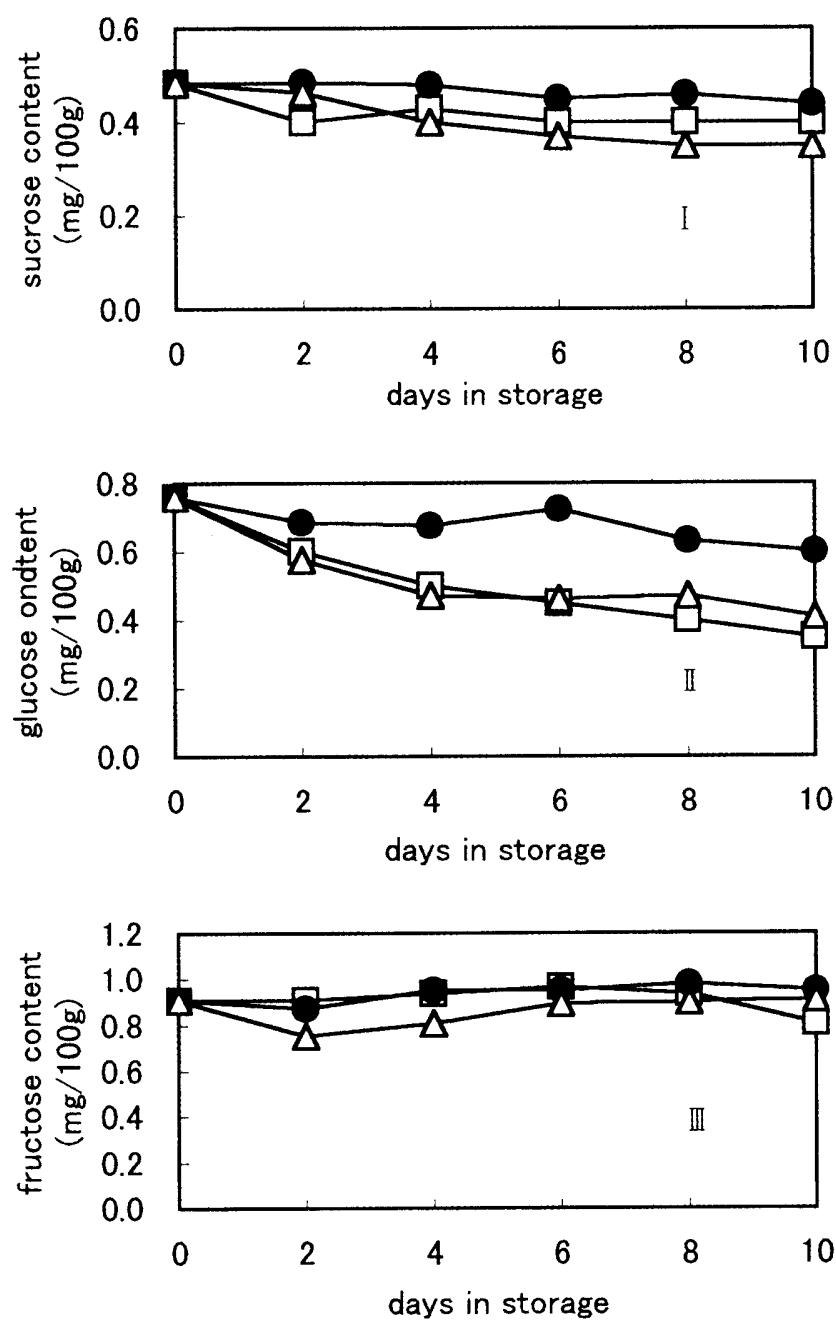

Fig. 4. Changes in sugar content in cut onion during storage at $10^{\circ} \mathrm{C}$. Symbols are the same as in Fig. 3. Data represent mean values of 4 determinations.

tent of onion packed in perforated $\mathrm{C}$ film decreased in the first 4 days, but then returned to the initial value (Fig. 4-III). It was unlikely that the fructose content of the other onions decreased during storage.

The changes in chlorophyll content of cut onions are shown in Fig. 5. The amount of chlorophyll in all onions was steady for

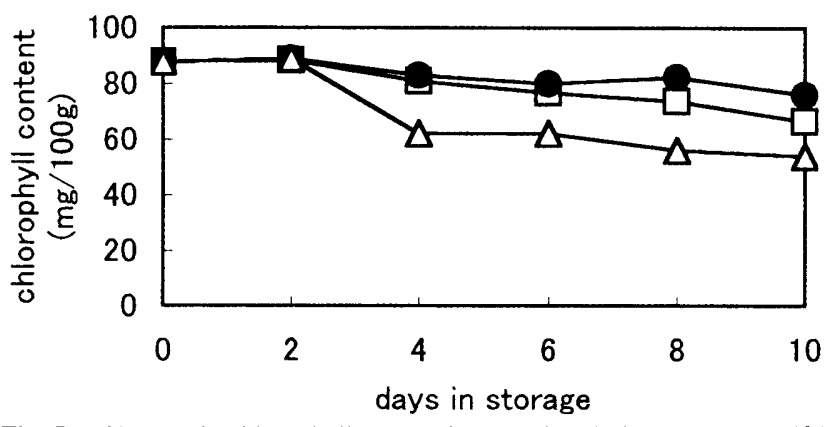

Fig. 5. Changes in chlorophyll content in cut onion during storage at $10^{\circ} \mathrm{C}$ Symbols are the same as in Fig. 3. Data represent mean values of 4 determinations.

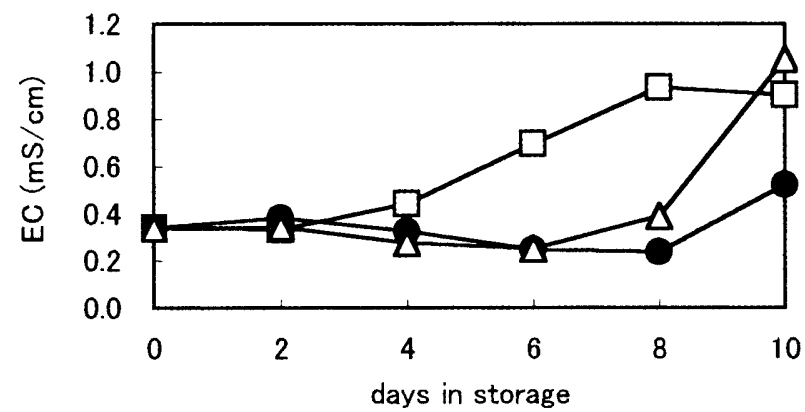

Fig. 6. Changes in electric conductivity in cut onion during storage at $10^{\circ} \mathrm{C}$. Symbols are the same as in Fig. 3. Data represent mean values of 4 determinations.

the first 2 days, but in onion packed in perforated $\mathrm{C}$ film, the content decreased rapidly after 4 days and slightly after that, while the content of the onions in other packaging decreased only slightly.

There was a marked increase in the degree of EC of the onion packed in unperforated film after 4 days of storage (Fig. 6). The EC of the onion packed in perforated B and C film decreased gradually during 8 and 6 days of storage, respectively, and thereafter began to increase.

Quality of the onions is shown in Table 2. Cut onion packed in unperforated film had an objectionable odor and spoiled rapidly owing to anaerobic respiration after 4 days of storage; moreover, the cellular tissue became water-soaked. These changes worsened as storage time increased. The onion retained a marketable quality for only 2 days and was inedible after 6 days of storage. The onion packed in perforated $\mathrm{C}$ film had an off-odor and was markedly spoiled; it retained a marketable quality for 4 days but was inedible after 8 days of storage. In contrast, the onion packed in perforated B film produced an off-odor and spoiled gradually because the atmosphere surrounding it was unsuitable for cut Welsh onion. It thus retained a marketable quality for more than 6 days of storage.

\section{Discussion}

The gas composition of a film package depends on the respiration rate of the commodity and the gas permeability of the film (Kader et al., 1989). The $\mathrm{O}_{2}$ concentration in the unperforated OPP film package decreased rapidly to $2 \%$ while the $\mathrm{CO}_{2}$ con- 
Table 2. Results of the sensory evaluation

\begin{tabular}{|c|c|c|c|c|c|c|c|c|c|c|c|c|}
\hline \multirow{3}{*}{ Property } & \multicolumn{6}{|c|}{ Off-flavor } & \multicolumn{6}{|c|}{ Total quality } \\
\hline & \multicolumn{6}{|c|}{ Days in storage } & \multicolumn{6}{|c|}{ Days in storage } \\
\hline & 0 & 2 & 4 & 6 & 8 & 10 & 0 & 2 & 4 & 6 & 8 & 10 \\
\hline A & 4.0 & 3.6 & 1.2 & 0 & 0 & 0 & 4.0 & 3.8 & 1.2 & 0.3 & 0 & 0 \\
\hline B & 4.0 & 3.6 & 3.4 & 2.5 & 2.0 & 2.0 & 4.0 & 4.0 & 3.1 & 2.5 & 1.8 & 1.5 \\
\hline $\mathrm{C}$ & 4.0 & 3.4 & 2.8 & 1.7 & 0.5 & 0.5 & 4.0 & 3.8 & 3.0 & 1.7 & 0.5 & 0.8 \\
\hline
\end{tabular}

Off-flavor and total quality of cut Welsh onion in each package were evaluated using a rating scale of 4 to 0 . A rating of 4 indicated quality comparable to that just after cutting, a rating of 2 indicated marketable, a rating of 0 indicated inedible. Data represent mean values of 4 determinations. A: unperforated OPP film, B: OPP film with 24 micro-perforations per package, C: OPP film with 48 micro-perforations per package.

centration increased, because the permeabilities of these gases were too low for Welsh onion. In addition, the respiration rate was higher for cut than whole Welsh onion (data not shown). Kader (1987) described that anaerobic respiration and total $\mathrm{CO}_{2}$ production increase when the $\mathrm{O}_{2}$ concentration drops to less than $2 \%$. Therefore, it seems reasonable to suppose that the onion was induced to respire anaerobically. This supposition is supported by the fact that this onion produced ethyl alcohol whereas the onions packed in more permeable film did not. Moreover, the cellular tissue of this onion became water-soaked; this phenomenon occurred when the Welsh onion respired anaerobically (Ibaraki et al., 1997b).

The $\mathrm{O}_{2}$ concentration in the perforated $\mathrm{C}$ film package decreased slightly to $16 \%$ because the gas permeability was too high; ethyl alcohol was thus not detected and the chlorophyll content decreased considerably. In addition, the amount of sugar, generally considered the respiratory substrate, decreased gradually: glucose content droped by about $50 \%$ within 10 days. These phenomena occurred when the atmosphere surrounding the Welsh onion was the same or nearly the same as air (Ibaraki et al., 1997a).

A beneficial $\mathrm{O}_{2}$ level for MAP of whole Welsh onion seemed to be $4-5 \%$ at $20^{\circ} \mathrm{C}$ (Ibaraki et al., 1995). MAP maintained the quality of whole Welsh onion by reducing the rate of respiration (Ibaraki et al., 1997a), and by the loss of chlorophyll and sugar (Ibaraki et al., 1999). The $\mathrm{O}_{2}$ concentration in the perforated $\mathrm{B}$ film package was not considered to be as low as for MAP in this vegetable, but it decreased to $10 \%$, so the chlorophyll and sugar contents were comparatively retained. Therefore, the cut Welsh onion was considered marketable for 6 days.

The degree of EC increases when compounds of a cut vegetable, like potassium, leak out into water through the cut end or openings of the cellular tissue. Usually the EC decreases gradually due to callus or drying of the cut end, and begins to increase when the cellular tissue is broken due to collapse (Ibaraki et al., 1988). In unperforated(A), perforated $B$ and perforated C film, the day on which the EC began to increase was 4, 10 and 8, respectively. These days approximately corresponded with the day on which cut onion became inedible, indicating that the measurement of EC is an effective means of confirming the quality of cut onion.

These results suggested that the gas permeability of the OPP film was too low to maintain the gas conditions for cut Welsh onion; an OPP film with micro-perforations was therefore made available to prevent the deterioration caused by anaerobic respiration. Too many micro-perforations were ineffective, however, because the $\mathrm{O}_{2}$ concentration in the package was too high to maintain the MAP condition. OPP film with 24 micro-perforations (diameter: $50 \mu \mathrm{m}$ ) per package (thickness: $0.02 \mathrm{~mm}$, effective area: $0.043 \mathrm{~m}^{2}$, free volume, $350 \mathrm{ml}$ ) was effective for cut Welsh onion $(50 \mathrm{~g})$.

\section{References}

Bergmeyer, H.U. and Bernt, E. (1974). Methods of Enzymatic Analysis (2). Verlag chemie weinheim, Academic Press, Inc., New York and London, pp. 1176-1179.

Beutlar, H.O. and Michal, G. (1977). Neue methode zur enzymatischen bestimmung von ethanol in lebensmitteln. Anal. Chem., 284, 113.

Hirata, T., Makino, Y., Ishikawa, Y., Katsuura, S. and Hasegawa, Y. (1996). A theoretical model for designing modified atmosphere packaging with a perforation. Trans. Am. Soc. Agric. Eng., 39, 1499-1504.

Ibaraki, T., Matsumoto, A., Hirano, T. and Yamashita, S. (1988). Studies on techniques for storage and packing of Welsh onions: (1) Method for evaluation and keeping freshness of Welsh onions. Bull. Fukuoka Agric. Res. Cent., B-7, 101-104 (in Japanese).

Ibaraki, T., Ikeda, H., Uchida, H. and Ohta, H. (1995). Effects of polypropylene film packaging and shipping containers on quality stability of Welsh onion(Allium fistulosum L.). J. Jpn. Soc. Cold Preserv. Food, 21, 67-72.

Ibaraki, T., Ikeda, H. and Ohta, H. (1997a). Effects of several atmosphere compositions on keeping quality of Welsh onion(Allium fistulosum L.). Food Preserv. Sci., 23, 3-7.

Ibaraki, T., Ikeda, H. and Ohta, H.(1997b). Effects of harvest season on respiration rate, chemical components and quality stability in Welsh onion(Allium fistulosum L.). Food Preserv. Sci., 23, 77-82.

Ibaraki, T., Ikeda, H. and Ohta, H. (1999). Effect of polypropylene film packaging and storage temperature on chemical components and quality stability of Welsh onion. Food Sci. Technol. Res., 5, 9396.

Kader, A.A. (1987). Respiration and gas exchange of vegetables. In "Postharvest Physiology of Vegetables" ed. by J. Weichmann, pp. $25-43$.

Kader, A., Zagory, D. and Kerbel, E. (1989). Modified atmosphere packaging of fruits and vegetables. Crit. Rev. Food Sci. Nutr., 28, $1-$ 30 .

Sugawara, T., Kawano, S., Shiina, T. and Ohta, H. (1987). Quality control of shredded lettuce during preservation and distribution. $J$. Jpn. Soc. Cold Preserv. Food, 13, 92-98.

Wintermas, J.F.G.M and Demonts, A. (1965). Spectrophotometric characteristics of chlorophylls a and $\mathrm{b}$ and their pheophytins in ethanol. Biochim. Biophys. Acta., 109, 448-453. 